\title{
Insect Atlas as a Learning Resource for Diversity of Insect
}

\author{
Eka Yulianti", Zumrotun Ni'mah, Lili Shafdila Nursin \\ Biology Education Department, Faculty of Science and Technology, UIN Sunan Kalijaga \\ Jl. Marsda Adisucipto No 1 Yogyakarta 55281, Indonesia. Tel. +62-274-540971, Fax. +62-274-519739 \\ *Email: yatra.lian@gmail.com
}

\begin{abstract}
Diversity of insect is a biological theme that allows direct knowledge and experience of learning for student. The author describes 24 order and 34 species of JAZ (Jogja Adventure Zone), Candi Abang, and Liwa Lampung Barat. The research on insect as a source of learning is rarely done. Learning resources in the form of insect diversity atlases can help students to understand insects completely. The author develops a colorful atlas of an insect order using Corel Draw X5 software through the identification of indicator to be achieved, preparation of materials, layout design, and product printing. the product was assessed by 1 material expert, 1 media expert, 3 peer reviewer, 2 biology teachers and tested by 15 high school/MA students using checklist questionnaire. The result of the overall assessment of the colored atlas of the insect's diversity showed very good qualifications with an assessment percentage $88,9 \%$ and the response of students showed very good qualifications with a percentage $91,2 \%$.
\end{abstract}

Keywords: Colorful atlas, Diversity of insect order, Learning resource

\section{INTRODUCTION}

The insect is a member of the phylum Arthropods which has a distinctive body characteristic. The insect body consists of 3 parts, the head is composed of 3 segments, the chest consists of 3 segments, and the stomach consists of 11 segments (Hadi et al., 2009). Insects can also be called hexapods or animals that have 3 pairs of feet (Aziz, 2008). Insects have a high reproductive rate to preserve their offspring, there are some insects that can produce several generations in a year. Insect foods include stems, roots, leaves, fruits, seed, pollen from plants (Jasin, 1987).

Insects are a class of members of the phylum Arthropods which has the most members of the species on earth. The total number of species on earth, $75 \%$ or about 1,200,000 species are insects (Borror and DeLong, 1970). The large number of insect species and grouping of insects causes students difficulty in memorizing the scientific names of each species (Henny, 2012). In facilitating students in learning the material of insect diversity, a companion book is needed in addition to textbooks which are only in the form of reading texts. Atlas Insect can be the right companion book for students to understand insecticidal material because it contains pictures and descriptions of Insecta species that are in the environment around the students (Andi, 2011).

\section{MATERIALS AND METHODS}

This research was conducted from October 2017 to February 2018 and the location of the insect sampling was in the area of JAZ (Jogja Adventure Zone), Candi Abang, and Liwa West Lampung. Insects studied, representing each order. The tools and materials used in this study are Canon EOS 600D DSLR cameras, alcohol, cotton, insect nets, syringes, jars, chlorophyll, and even magnifiers. The steps in this study began with the classification of the diversity of insect species from several regions of JAZ, Candi Abang, and Liwa, West Lampung according to their order, then carried out the development of the insect order atlas, designed the atlas of the diversity of insect orders, and tested the atlas of the diversity of insect orders. The research chart is as follows:

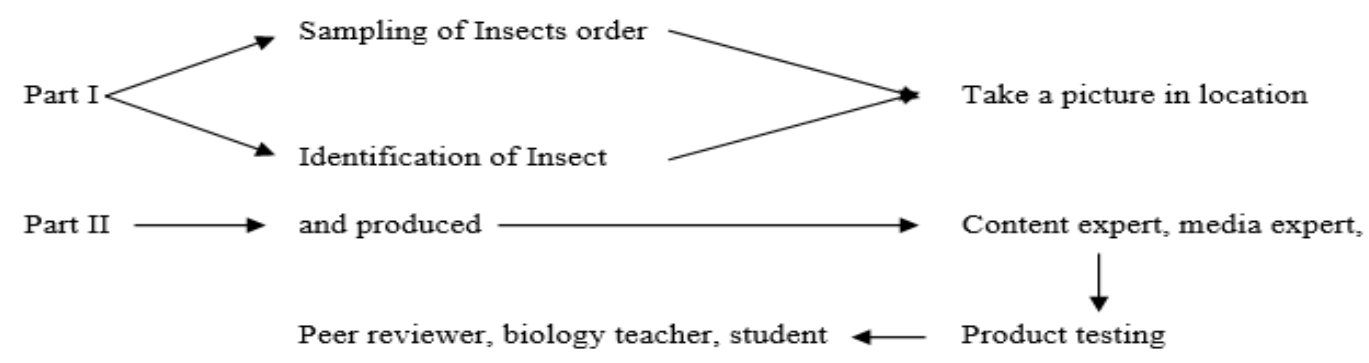

Figure 1. Research method of insects atlas. 
The data analyzed in this study is the process of product development and the quality of products produced.

\section{RESULTS AND DISCUSSION}

\section{Diversity of Insects Order}

Based on the identification of insects obtained, 34 species of 24 insect orders were found, which are presented in the following table 1 .

Table 1. List of species of insects order.

\begin{tabular}{|c|c|c|c|c|c|}
\hline No. & Ordo & Species & No. & Ordo & Species \\
\hline \multirow[t]{2}{*}{1.} & Hemiptera & Pyrrhocoris apterus & 10. & Blattaria & Gromphadorhina portentosa \\
\hline & & Palomena prasina. & & & Periplaneta australasiae \\
\hline \multirow[t]{2}{*}{2.} & Homoptera & Tibicen linnei & 11. & Dermaptera & Forficula auricularia \\
\hline & & Megiciccadas eptendecim & 12. & Isoptera & Captotermes curvignathus \\
\hline \multirow[t]{2}{*}{3.} & Neuropteran & Myrmeleon formicarius & 13. & Diptera & Musca Domestica \\
\hline & & Cyrysopa perla & & & Lucillia sericata \\
\hline \multirow[t]{2}{*}{4.} & Odonata & Orthetrum Sabina & 14. & Mecoptera & Boreus hyemalis \\
\hline & & Iscnura heterosticta & 15. & Plecoptera & Nemoura cinerea \\
\hline \multirow[t]{2}{*}{5.} & Orthoptera & Tenodera sinensis & 16. & Shiphonaptera & Ctenocephalides felis \\
\hline & & Gryllus assimilis & 17. & Ephemeroptera & Hexagenia bilineata \\
\hline \multirow[t]{3}{*}{6.} & Coleoptera & Lucanus cervus & 18. & Trycoptera & Platycentropus radiates \\
\hline & & Coccinella transversalis & 19. & Phasmida & Melanoplus femurrubrum \\
\hline & & Chondropyga dorsalis & 20. & Thysanoptra & Thrips tabaci \\
\hline 7. & Hymenoptera & Oecophylla smagaragdina & 21. & Psocoptera & Tineola bisselliella \\
\hline \multirow[t]{2}{*}{8.} & Lepidoptera & Euphydryas Cynthia & 22. & Stresiptera & Elenchus tenuicornis \\
\hline & & Barbo cinnara & 23. & Phthiraptera & Pulex irritans \\
\hline 9. & Mantodea & Mantis religiosa & 24. & Zoraptera & Zorotypus hubbardi \\
\hline
\end{tabular}

The area under study is several areas that have the potential for insect diversity which includes Jogja Adventure Zone, Candi Abang, and Liwa West Lampung. Based on the research conducted, 34 species from 24 orders were obtained. Each average order is found to be 1 or a species. Among the orders that are commonly found are 3 species of members of the Coleoptera order which have characteristics on the wing structure, namely 2 pairs of thickened front wings and 2 pairs of thin webbed rear wings (Borror et al., 1996). Also found were two species of members of the Hemiptera order that had the characteristic hemelytron wing type. The usually piercing, suctioning part of the piercing hemiptera's mouth generally extends ventral back to the body sometimes just at the base of the limbs (Borror et al., 1996). As for some of the results of the shooting obtained include.

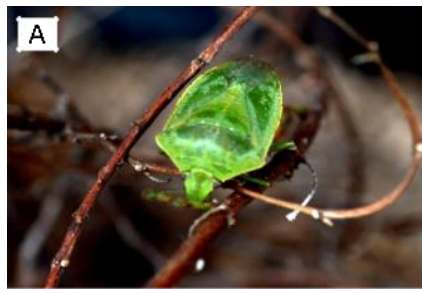

Figure 2. Palomena prasina.

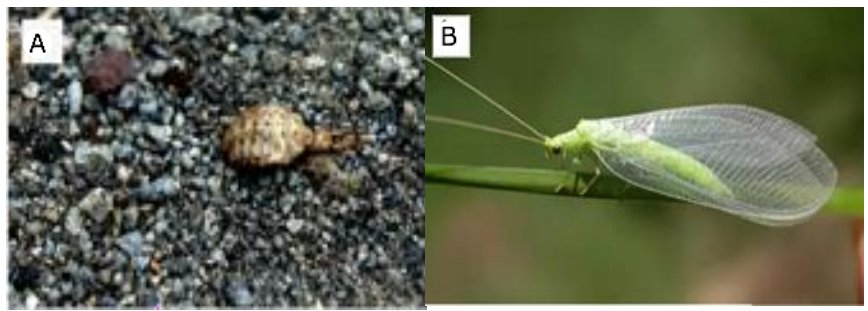

Figure 6. Mymeleon formicarius.

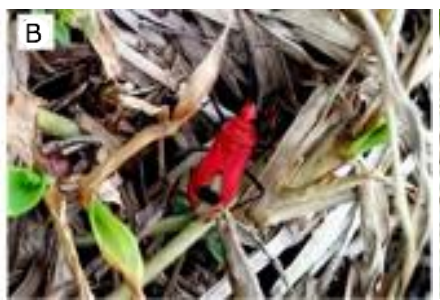

Figure 3. Pyrrhocoris apterus.
Figure 7. Cyrysopa perla.

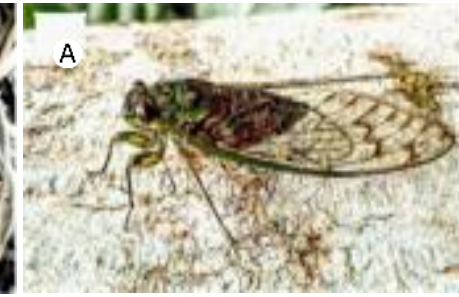

Figure 4. Tibicen linnei.

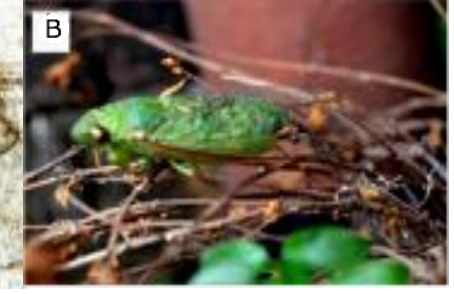

Figure 5. Magicicada septendecium.

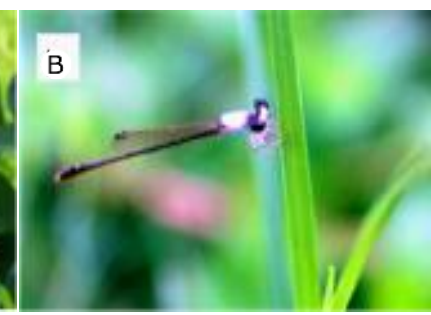

Figure 9. Ischnura heterosticta.
Figure 8. Orthetrum sabina.

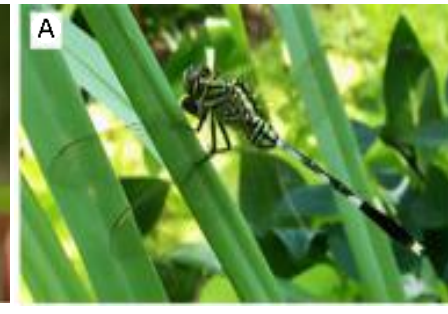




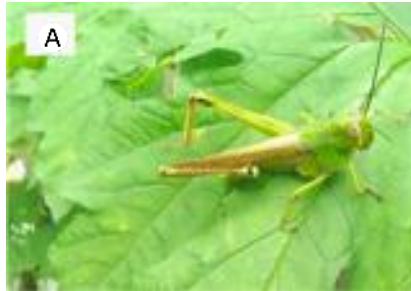

Figure 10. Tenodera sinensis.

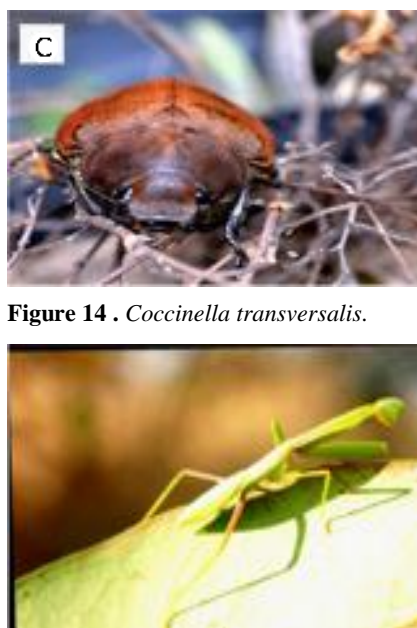

Figure 18. Mantis religiosa.

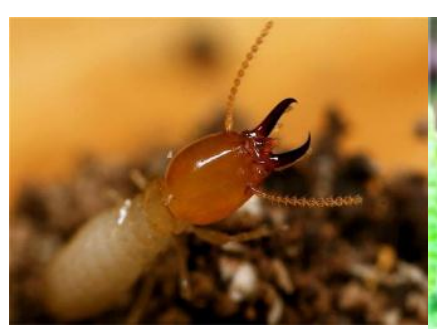

Figure 22 . Captotermes curviganthu.

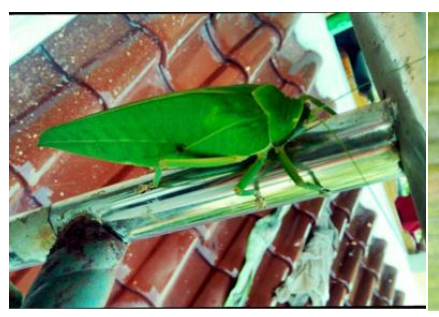

Figure 26. Melanoplus femurrubrum.

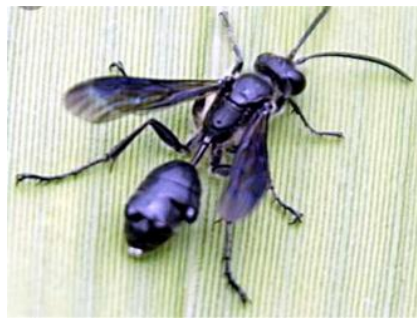

Figure 30 . Elenchus tenuicornis.

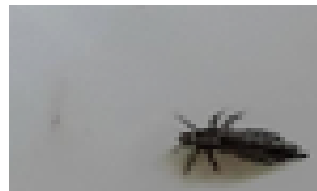

Figure 34. Pulex irritans.

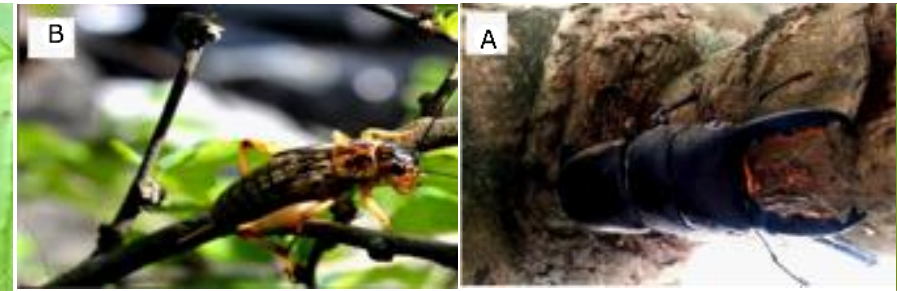

Figure 11. Gryllus assimilis.

Figure 12. Lucanus cervus.

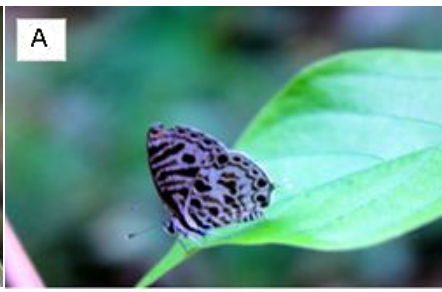

Figure 16. Barbo cinnara.

Figure 15. Oecophylla smagaragdina.

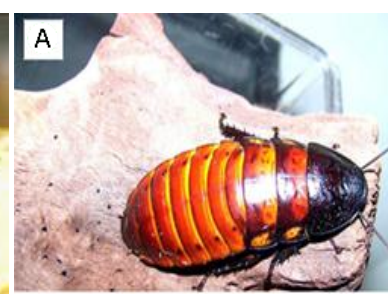

Figure 19. Gromphadorhina portentosa

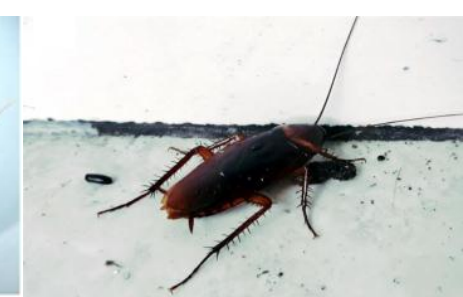

Figure 20. Periplaneta australasiae.

Figure 21. Foficula auricularia

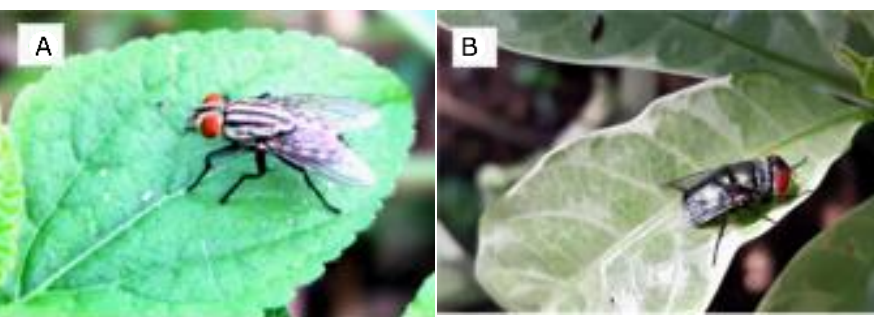

Figure 23. Musa domestica.

Figure 24. Lucilia serica.

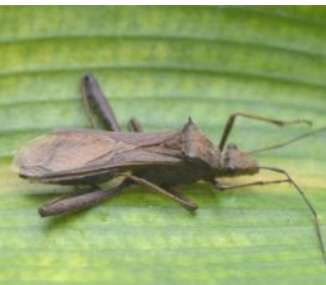

Figure 27. Nemoura cinerea.

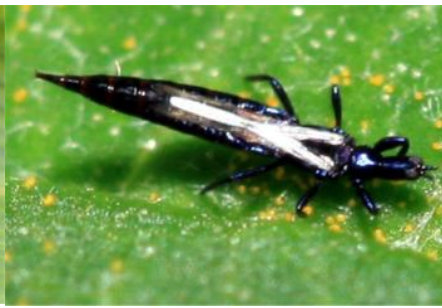

Figure 28. Thrips tabaci.

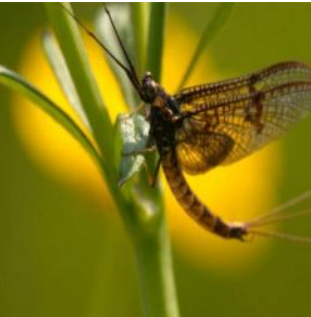

Figure 31. Hexagenia bilineata.

Figure 32. Tineola bisselliella.

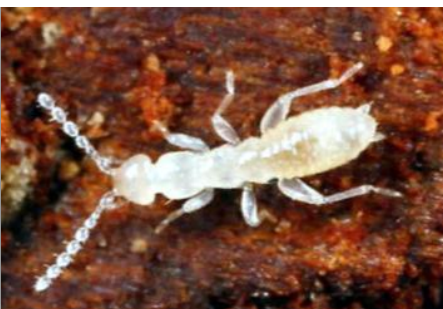

Figure 35. Zorotypus hubbardi.

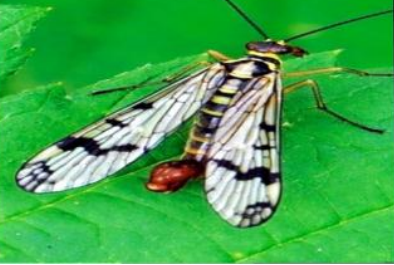

Figure 25. Boreus hymalis.

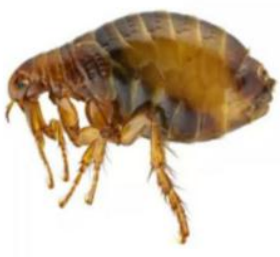

Figure 29. Ctenocephalides felis.

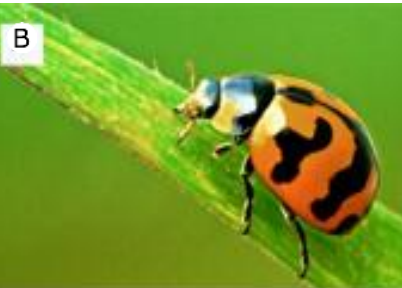

Figure 13. Chondropyga dorsalis.

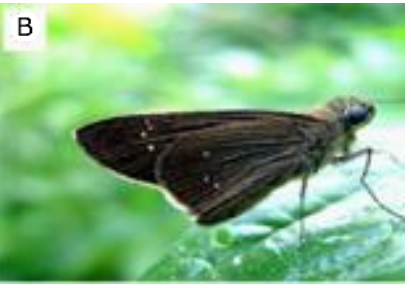

Figure 17. Ischnura heterosticta.
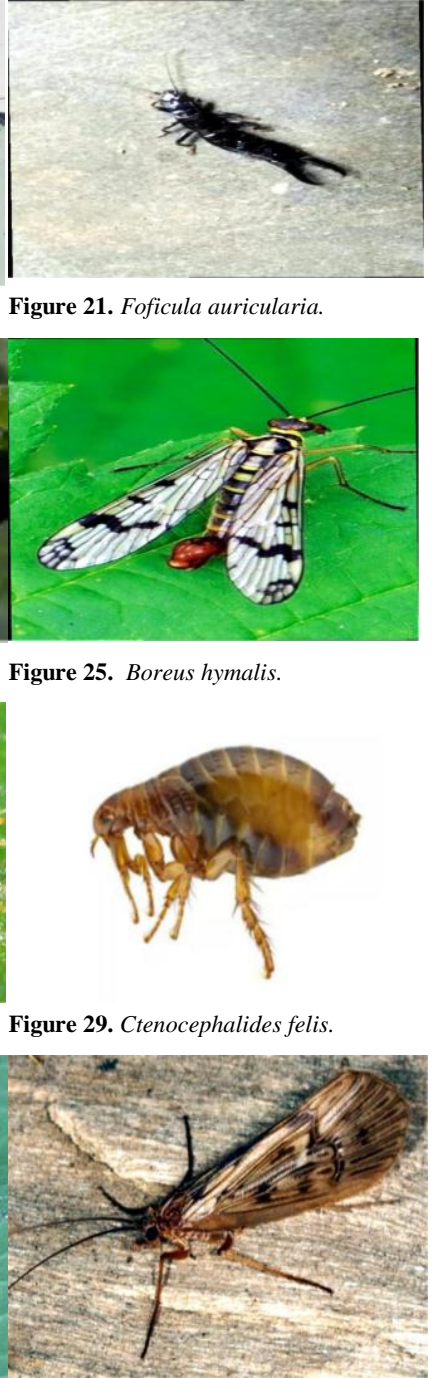

Figure 33. Platycentropus radiatus. (n)

(n)


The Development of Insect Atlas Diversity the Quality of Colored Insect Atlas

The development product is in the form of Atlas of Diversity of Insect Order. The framework for Color Atlas writing comes from direct observations in the JAZ (Jogja Adventure Zone), Candi Abang, and Liwa Regions in West Lampung. There are 34 types of insects found from observations. The data collected is in the form of photos of Insect species and other alternative photos included in the source. Corel Draw X5 application is used for the preparation of color atlas contents and designs. The paper used in the pictorial atlas section is 80 gram HVS paper and Ivory 230 gram paper for the cover. The front cover design is made attractive so that students' interest in reading can grow.

According to Arsyad (2013: 113) images and morphology of content in the atlas of the diversity of Insecta orders can attract attention and facilitate students' understanding. Based on Komalasari (2010: 75), images in learning media will stimulate thinking skills because they are concrete compared to reading material that is abstract or without images. This shows that the diversity of the Atlas of Insecta has been developed in accordance with its function as a learning resource.

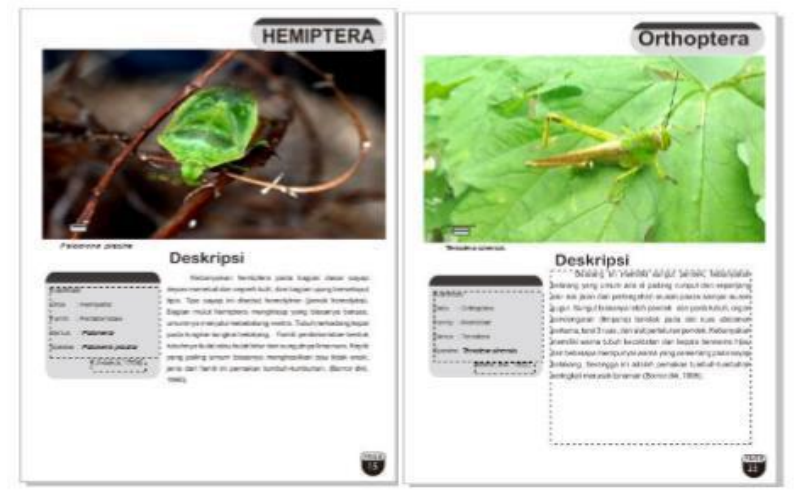

Figure 35. Part of the contents of the atlas of the insect's order diversity.

\section{The Quality of Colored Insect Atlas}

Atlas of the diversity of insect orders that have been developed further by media experts, material experts, peer reviewers, biological teachers, and students to find out the quality of the product (Wulansari et al., 2015). The assessment carried out by considering several aspects, presentation of material, display components, completeness of atlas, list of languages, etc. The results of critics showed very good cumulative category (SS), with an ideal percentage of $89.07 \%$. The results of the atlas validation of the diversity of insect orders are seen in table 2.

Based on the results of the assessment, shows that the product is quite good because the ideal percentage is above $61 \%$, and can be said to be feasible if the validity is above $70.01 \%$ (Akbar, 2013). This shows that the diversity atlas of the order of insects has several advantages, namely the material that is summarized and equipped with drawings, as well as attractive layouts that make learning more enjoyable for students (Arsyad, 2013). Diversity Atlas of insectic orders can be a companion book for students in addition to textbooks on invertebrate material, to facilitate students in mastering various unknown species (Andi, 2011).

Table 2. The results summary of the insect atlas diversity validation.

\begin{tabular}{|c|c|c|c|}
\hline Validator & Aspect assessed & $\begin{array}{l}\text { Average } \\
(\%)\end{array}$ & Cumulative \\
\hline $\begin{array}{l}\text { Content } \\
\text { expert }\end{array}$ & $\begin{array}{l}\text { - Presentation } \\
\text { - Contents } \\
\text { - Content eligibility } \\
\text { - Language component }\end{array}$ & 92,4 & Verry good \\
\hline $\begin{array}{l}\text { Media } \\
\text { expert }\end{array}$ & $\begin{array}{l}\text { - Display and graphics } \\
\text { components } \\
\text { - Language component } \\
\text { - Completeness of atlas }\end{array}$ & 88,5 & Very good \\
\hline $\begin{array}{l}\text { Peer } \\
\text { reviewer }\end{array}$ & $\begin{array}{l}\text { - A graphical display } \\
\text { - Component } \\
\text { Language component } \\
\text { - Completeness of atlas } \\
\text { - Presentation of } \\
\text { - Biology contents }\end{array}$ & 85,5 & Very good \\
\hline $\begin{array}{l}\text { Biology } \\
\text { teacher }\end{array}$ & $\begin{array}{l}\text { - Display component } \\
\text { - Language component } \\
\text { - Completeness of atlas } \\
\text { - Presentation of } \\
\text { - Biology content }\end{array}$ & 89,9 & Very good \\
\hline $\begin{array}{l}\text { Student } \\
\text { response }\end{array}$ & $\begin{array}{l}\text { Display and graphic } \\
\text { - Components } \\
\text { - Language component } \\
\text { - Completeness of atlas } \\
\text { - Presentation of } \\
\text { - biology content }\end{array}$ & 91,24 & Very good \\
\hline
\end{tabular}

\section{CONCLUSIONS}

Based on the research that has been done, the following conclusions are obtained:

1. There is a diversity of insect orders of 24 orders and 34 species of insect diversity studied by researchers, namely: Order of the order ephemeroptera, order of siphopnaptera, order of phasmida, order of mantodea, order of blattaria, order of psocoptera, order of odonata, order of orthoptera, order of isoptera, order of placoptera, order dermaptera, Order Zoraptera, Order of Thysanoptera, Order of Hemiptera, Order of Homoptera, Order of Neuroptera, Order of Coleoptera, Order of Strepsiptera, Order of Mecoptera, Order of Trichoptera, Order of Lepidoptera, Order of Diptera, Order of Hymenoptera, Order of Phthiraptera.

2. The diversity of insect orders was developed into a color atlas through the stages of inventorying and taking pictures of insects making materials, designing layouts, product revisions and validation from experts. 
3. The quality of the insect diversity atlas based on the reviewer's assessment and the student's response shows very good qualifications.

\section{ACKNOWLEDGMENTS}

The author would like to thank to the management of apprenticeship program of faculty of science and technology for guidance during the research, to the management of biology, medicine and natural product chemistry \& kaunia journal for assistance in paper writing.

\section{REFERENCES}

Andi, Prastowo. 2011. Panduan Kreatif Membuat Bahan Ajar Inovatif. Yogyakarta: Diva Press

Alimul Aziz, H. 2008. Pengantar Konsep Dasar Keperawatan. Edisi 2. Jakarta: Salemba Medika.

Borror, D.J. dan D.M. DeLong, 1970. An Introduction to The Study of Insect. Third Edition. New York: Holt, Rinehart and Winston.

Hadi, Mochammad, Udi Tarwotjo dan Rully Rahardian. 2009. Biologi Insekta Entomologi. Yogyakarta: Graha Ilmu.

Jasin, Maskoeri. 1987. Ilmu Alamiah Dasar Untuk Perguruan Tinggi dan Umum. Surabaya: Bina Ilmu.

Komalasari. 2010. Pembelajaran kontekstual: Konsep dan Aplikasi. Bandung: PT Refika Aditama

Wulansari, D. L. 2015. Pengembangan Atlas Keanekaragaman Tumbuhan: Euphorbiales, Myrtales, dan Solanales sebagai sarana Identifikasi. Jurnal BioEdu. 4 (3): 1030. 
THIIS PAGE INTENTIONALLY LEFT BLANK 